\title{
Policy Analysis of Socio-Economic Development of Coastal Areas in Central Java Province
}

\author{
Manik Suryandaru Raka Timur ${ }^{1}$, Ari Pradhanawati ${ }^{2}$, Hartuti Purnaweni ${ }^{3}$, Kismartini ${ }^{4}$ \\ \{pradhanawatiari@rocketmail.com²\} \\ Universitas Diponegoro, Indonesia ${ }^{1,2,3,4}$
}

\begin{abstract}
This research aims to analyze and describe the policy of socio-economic development of coastal areas in Central Java Province. As it known that, the current level of social and economic welfare of coastal communities in this province has decreased annually. By using the study method of literature so that it could learned that the policy development of coastal areas at national level and Central Java Province is not optimal. It is because the policy of the central government to the area in developing the coastal areas socially and economically not implemented in accordance with the existing regulations. Recommendations give to be in line with the research results finding. In addition, they could provide for current government are: (1) Formulating the policies development, especially local governments, who are more concerned and favoring the angler's community interests. (2) Revitalize the position and Field Counseling Officer (PPL) role of fisheries in the fishing villages so that they are more empowered and knowledgeable to develop the road development of coastal areas and anglers' communities in an integrated and sustainable way. Field Counseling Officer ( $P P L)$ fisheries are a development broker that serves as a bridge of interest between the country and the anglers' community in the development of coastal communities.
\end{abstract}

Keywords: Public Policy, Coastal Anglers, Poverty, Fishery Exchange Rate (NTP), Central Java Province

\section{Introduction}

Coastal areas are an important region to review from various planning and management perspectives. The Ministry of Marine Affairs and Fisheries in the draft of the Integrated Coastal Area Management Act has incorporated coastal areas as a transitional region that connects land ecosystems and marine ecosystems located between the boundary and land boundaries as far as the highest tide and towards the sea as far as the influence of inland activities [1].

Coastal areas have high economic value, but are threatened in continuation. With its unique potential and economic value then coastal areas are faced with a high threat, then the coastal area should be handled specifically so that the region can be managed sustainably [2]. Considering the current Indonesia has a large capital to be able to maximize the condition. Because currently Indonesia is the second country whose has the second longest coastline after Canada. That can be seen in the following figure 1 . 


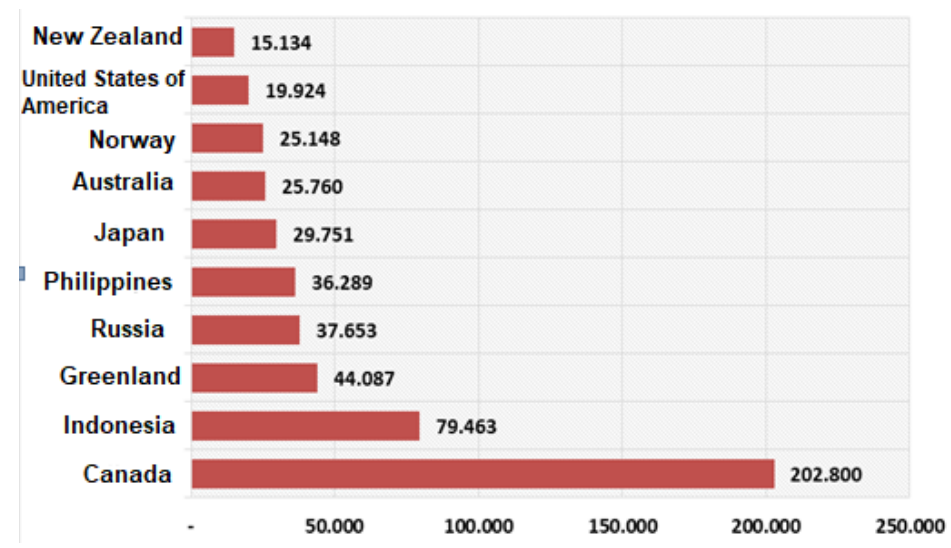

Fig. 1. The country with the longest coastline in the world (km) [3].

Based on the figure above, it is known that Indonesia is a country with the second longest coastline $(79,463 \mathrm{~km})$, whereas Canada has the first longest coastline $(202,800 \mathrm{~km})$, and for Asian countries, Philippines ranks five worlds with a long line of $36.289 \mathrm{~km}$ of beaches, and Japan ranks six with a long line of $29,751 \mathrm{~km}$ of beaches. Indonesia, as the archipelago with the largest number of islands in the world and has the length of the world's second longest coastline has potential resources Abundant sea and coast [4].

This potential not only has a high economic value, but also has a social value that can be used to develop coastal areas in Indonesia but the above conditions have not been able to be utilized optimally, because the area that is utilized to improve the community in the coastal area is very limited [5].

The Area of fisheries in the coastal of Indonesia decreased even though in 2015, there was a slight increase but the amount could not return as in 2013, and in 2016 decreased again. In fact, if viewed based on National Statistic Agency (BPS) data, it is known that the current percentage of the seaside village in Indonesia amounted to $15.32 \%$, and the percentage of the seaside village in the Central Java province is currently $4.15 \%$.

\section{Literature Review}

In terms of public policy, understanding there is much of meaning depending on the angle where we interpret it [6]. Provided a definition of public policy as the authoritative allocation of values for the whole society or as a forcibly allocation of values to all members of the community [7]. It also defined public policy as a capacitance program of goal, value, and practice or something of achievement programs, values in directed practices.

Public policy according to Dye [8] defined as "Whatever government chooses to do or not to $d o^{\prime \prime}$. Public policy is what the government chose to do or did not do something. This understanding indicates that the government has the authority to make choices about which policies will be performed or not, depending on the issues arising or the achievement that is intended to be addressed by the policy. Meanwhile, the policy sense expressed by Goodin, Moran and Rein [9] defined public policy as a series of actions proposed by a person, group or Government in a particular environment, with existing threats and opportunities, where the 
proposed policy is intended to capitalize on the potential and overcome existing barriers in achieving certain objectives.

Not much different from the opinion of the experts above Dye [10] suggested that in the policy system there are three elements of "(a) Stakeholders policy; (b) Policymakers (policy contents); and (c) policy environment". Based on the theory, you can be aware that a policy is made by the Government to achieve certain objectives in which there are perpetrators involved in addressing the problems arising from the environment.

Another sense of policy analysis is put forward by Dunn [11], which stated that in general policy analysis can be said to be an intellectual and practical activity aimed at creating, critically assessing and communicating knowledge about and within the policy process.

Policy Analysis is the beginning, not the end, of the effort to improve the policy-making process. In addition, Weimer and Vining [12] as a planned and systematic effort to make accurate analysis submitted policy analysis or assessment of policy consequences, both before and after the policy is implemented. The explanation above suggests that policy analysis should be empirically in the sense that the judgment is not only allowed to be hypothesizing speculative, but also must be tested or issued with data or at least the results of the research ever undertaken.

\section{Method}

Analysis of the study was conducted through a review of literary studies related to several policy issues of socio-economic development in coastal areas at the national level up to the province. By using the study method of literature, the coastal development is known and studied with several literature and previous research results that have been conducted by several researchers through survey methods in several countries. Combined with National Statistic Agency (BPS) data and current policy regulations in the analysis and describing the policy of social economic development of the coastal region in Central Java Province.

By using a face-to-face survey method, the study collects data from 102 anglers. Research findings show that the majority of anglers, who are regularly researched need information on the weather, buy and sell prices of fish, daily consumption products, entertainment, and religion. Anglers in this study rely heavily on their informal information network (e.g., family and friends) to cater to their diverse needs of information. However, it is not done by various government agencies, because the information is only given to the educated community.

\section{Result and Discussion}

The community of anglers whose income source is based on water is an integral part of this nation that can be spearheading empowerment of sub-sector resources of water and maritime in filling the economic development of the archipelago. The role of the spearhead in filling the development can only be realized if its role is empowered, recognized protected, and there is a guarantee of legal certainty that is in the case of those whose main source of livelihoods is from the waters. In addition to the challenges of nature faced by very heavy fishermen (seasons), a homogeneous work pattern that relies on only one source of income, various other issues that chasten fishermen and a question of classical decay.

The ability of weak capital, fish selling price games, and limited power of fish processing industry is still a problem that has not been resolved. Apart from that, the sophisticated power 
of the fleet catches foreign anglers who catch fish illegally. The limited mastery of science and technology of the processing of the catches and the absence of government policy to them is a problem in the competitiveness of small and traditional anglers nowadays.

Their lives are very concern because as traditional anglers who belong to the group of poor people, the owners of capital or brokers often use them as an object of exploitation, so that the distribution of revenues becomes uneven. The technology used by them is generally still traditional. Therefore, productivity is low and ultimately low income. The symptom of the modernization of fisheries not only helps even make traditional anglers to be buried, such as the emergence of large-sized capture vessels and modern technologies. They are able to catch more fish than traditional anglers are using only traditional technology.

According to the Ministry of Transportation, the number data of anglers certified perFebruary 2019 the amount has reached 232,414, but in the last 10 years the number of anglers reduced by $25 \%$. Now there are 2.8 million heads of caught fishing families in the sea. There are several factors causing declining number of anglers based on findings from some areas. Firstly, the policy is unfortunate, because there is a waiver both by the Government and by industry that do pollution in the sea. Both there are called expulsion practices. This is clearly seen in the tourist industry area where anglers are not allowed to catch fish for the reason of the tourism area. While the data of Ministry of Maritime and Fisheries in 2018 showed, the number of anglers in Indonesia amounted to 2.7 million people. The majority of the population is within the threshold of poverty and accounts for $25 \%$ of national poverty.

The government Program that is running is the pro-poverty policy which is certainly also directed at the life improvement of fishermen and their families, the government claimed the number of poverty people in the country reached 25.95 million people or $9.82 \%$ of the total population. One of the poverty roots of the angler's community is the limitation of accessing capital; the banking sector's alignments to the fishery sector are still being seen as full of risk, and a small budget. Policies those are not pro-poor to change the fate of anglers. Even politically, anglers are still often used as objects of mass mobilization for political purposes. The poverty of anglers is a complex and multi-dimensional morphing problem, both of structural and cultural aspects. According to Gai and Soemarno [13], poverty as an indicator of the alienation of coastal communities and fishermen is caused by 3 things: structural poverty, super natural, and cultural.

Structural poverty is caused by individual internal factors or variables i.e. socio-economic structure of the community, availability of incentives or disincentive development, availability of facilities, availability of technology, and natural resources as well. The higher is the intensity, volume and quality of the variables then the poverty decreases. Meanwhile, structural poverty based on Barrett and Carter [14] was the poverty suffered by the community, because the social structure of the community is not able to participate in the actual income sources available to them. Thus, structural poverty can be interpreted as an atmosphere experienced by a society whose causes are sourced to social structures that apply in the poor. The poorest caused by macro policy variables that are not or less parties to the development of anglers' community in the form of fiscal policy, monetary policy, the availability of laws and legislation of government policies implemented in the development project. The desire and willingness of both central and regional governments who have a strong commitment to the welfare of poor anglers are needed in the name of this problem.

Cultural poverty is due to inherent variables, being a certain lifestyle that causes individuals to be difficult out of poverty. This cultural poverty variable is caused by the level of education, knowledge, customs, culture, beliefs, adherence to certain deedless [15]. Divided four underlying problems that are the cause of poverty: (1) lack of opportunities (2) Low-ability (3) Lack of guarantee (low level Security) (4) Limitation of social rights, economic and political 
causes vulnerability, negligence (voice Lessons), and powerlessness (Power Lessons) in all fields [16].

There are 4 million heads of coastal communities living in 8,090 villages, apparently $32 \%$ of life with revenues of less than IDR 300 thousand per month or relatively poor. Although it is realized that the problem of anglers and poverty is only not occur in developing countries. In the developed world though, poverty of anglers will arise while there is an error management of fishery resources management.

Indonesia, which belongs to the marine country and archipelago of the world, has a wealth of natural resource end men in the marine and fisheries sectors abundant. Unfortunately, the vast potential of marine resources reaching $70 \%$ (5.8 million square $\mathrm{km})$ of its territory area is much larger than that of land (forestry), which is only 1.31 million square kilometers, is not optimally utilized. It is not only rich of various types of fish and another marine biota. The Indonesian Sea is also mineral-sourced and renewable energy. More ironic, anglers and coastal communities, is the poorest in the strata of the social Economic Community of Indonesia.

According to Indonesian regulation [17] about fisheries, fishermen are the ones whose livelihoods carry out fishing involving three main components, namely: human resources, fishing units, and fish resources. In general and be a portrait of the life of Indonesian fishermen, namely small fishermen with energy and fishing equipment simple, educated low, lack of knowledge and information, become a trade of Modular/Tooke large enough in their social economic life, both in production activities, marketing, even in fulfilling the daily needs. Hasanuddin, Noor and Santosa [18] explained that the poverty of the anglers was not an independent, but a result of a past policy that is too concentrated in the development of the maritime orientation, thus making the marine and fisheries a peripheral sector.

Being an irony for Central Java Province that has the potential of marine fish resources is estimated to reach $416,391.46$ tons per year, the pockets of poverty are mostly located in slum angler's area. Traditional anglers numbering about 167,072 people to date become the community is being constrained and still dwell on the circle of poverty. There are many factors cause the poverty of anglers, both scientifically, structurally, cultures are very complex and natural conditions that are very difficult to predict, and the destruction of nature makes the catches less.

To see the social and economic welfare of anglers in Central Java province, researchers use the Fishery Exchange Rate (NTP) data released by BPS. A Fisheries Exchange Rate (NTP) as a welfare measure is derived from a comparison of the amount of the price received (income), with the price paid by the angler (expenditure). With the NTP $(2012=100)$, which means that the increase in the production price is equal to the increase in consumption price so that the angler has a breakeven?

The welfare level of anglers in Central Java Province has not shown significant improvement when viewed from existing potentials. Administratively, the province of Central Java consists of 35 districts/cities with 17 districts/cities that have a sea area namely the North Coast 13 regencies/towns and the south coast of four counties. Central Java has a length of coastline $791.73 \mathrm{~km}$, consisting of the northern coastline of $289.07 \mathrm{~km}$ and $289.07 \mathrm{~km}$ of the southern coastline, with the potential of large enough fisheries and marine that is around 6.4 million tons/year.

The issue of coastal socio-economic development policy is not only happening in Indonesia but has become a Global problem, where it can be seen in some research that has been done by some of the following studies. Rahman et al. [19], in research he had done in Bengal, Bangladesh gives a picture of his research on the use certain concept tactics, strategies, and 
poverty information to examine the conditions of the angler's community in the Bay of Bengal region of Bangladesh.

Yusuff et al. [20] was conducting research in Terengganu, Malaysia with an interest in improving the quality life of anglers in the area. The results showed that the quality of life of anglers was at a moderate level. However, involvement of the parties involved especially stakeholders in rising the standard of anglers' life is crucial to achieving a higher level of income, and for the quality of life of anglers in Kuala Terengganu, Malaysia.

Angelopoulos, Kitsios and Papadopoulos [21] was conducted research aimed at identifying factors contributing to the quality of life of the fishing community in the west coast of peninsular Malaysia namely Selangor, Perak, Kedah and Johor. Correlation analysis shows the indicator of income, savings, housing, family environment and fishing equipment contributes to the enhancement of quality of life among anglers on the west coast of peninsular Malaysia. Qualitative analysis demonstrates the challenges faced by anglers, which affects the quality of their lives is competition with foreign anglers and the lack of artificial reefs to increase the number of fish in places where anglers focus on fishing.

FAO [22] mentioned that sustainable fisheries include the social status of anglers. That combines the quality of life empirical (QOL: Quality of Life) and subjective methods of life experience used to explore the social sustainability Of fishermen along the coast of Jalisco, Mexico, where the average daily income is slightly above the poverty line. The QOL Data obtained from the 12 interviewed anglers reveals that family and friends are important indicators related to their quality of life, while the economic indicators are assessed insignificant.

Although four people of five anglers argue that the future looks worse than it is current and past, there is a limited correlation between catches or income and quality of life. While in part life experience supporting QOL findings, where people are the most important dimension to almost all anglers interviewed, the negative economic gaps are associated with bad catches and revenues in the dimensions of mind and work. These findings suggest that to understand the socio-economic components of sustainable fisheries, both approaches should be considered, as they can illuminate various aspects of angler life to consider during the development of fisheries management policies conducted by the government.

\section{Conclusion and Suggestion}

Based on the discussion, this research proves that Experiential marketing significantly, positively influences customer loyalty through perceived value, which means that perceived value is able to mediate the influence of experiential marketing on customer loyalty. Facility significantly, positively influences customer loyalty through perceived value, which means that perceived value is able to mediate the influence of facility on customer loyalty. Accessibility significantly, positively influences customer loyalty through perceived value, which means that perceived value is able to mediate the influence of accessibility on customer loyalty. Perceived value significantly, positively influences customer loyalty. Higher perceived value will enhance customer loyalty and, on the contrary, when perceived value declines, customer loyalty will decline.

One of the most important factors for anglers to get public attention is the policy of development that has not been concerned about the maritime sector and fisheries as one of the future determinants of the nation. A further consequence is that society lacks sympathy and empathy for the survival of anglers. The community's attention gradually began to grow after the establishment of the Ministry of Maritime and Fisheries in 1999. Nevertheless, in the era of 
regional autonomy, the mission of central government to give serious attention to the development of maritime and fisheries sectors has not been fully integrated with the policy of local government development.

The nature of government policy and poor community attention, as well as in the midst of the various limitations of social, economic and political access, has made the fishermen community develop internal mechanisms, adaptation strategies, and build self-ability based on the potential resources available in the environment in order to survive. By being based on cultural values as a coastal community, fishermen have a high self-reliance nature in the face of the life-pressure oneness that comes at all times, because of this capacity of self-reliance they like to be "a community without country", cynical to the apparatus, and potentially resistant to state policies. Such attitudes are the inequality of the relationship between the country and the anglers who have lasted long enough.

The task of State and Government in the present and future is to knit again intensively the patterns of functional relations with anglers, so that the policy of development policies obtains positive response and responsibility of the angler's society. In line with the findings of the research above, the recommendations that can be given to the current government are:

1) Formulating the policies of development, especially local governments, who are more concerned and favoring the interests of the fishermen community as well.

2) Revitalize the position and role of PPL of fisheries in fishing villages so that they are more empowered and knowledgeable to hack the road of development of coastal areas and anglers' communities in an integrated and sustainable way. The PPL/PTL fisheries are a development broker that serves as a bridge of interest between the country and the angler's community in the development of coastal communities.

\section{References}

[1] KKP_RI, “Analisis Data Pokok Kementrian Kelautan dan Perikanan 2015,” Pusat Data, Statistik, dan Informasi. 2015.

[2] M. L. Martínez, A. Intralawan, G. Vázquez, O. Pérez-Maqueo, P. Sutton, and R. Landgrave, "The coasts of our world: Ecological, economic and social importance," Ecol. Econ., 2007.

[3] CIA, C. I. Agency, and C. Central Intelligence Agency, "CIA World Fact Book," httpwwwciagovciapublicationsfactbookgeosinhtml. 2011.

[4] R. Oberman, R. Dobbs, A. Budiman, F. Thompson, and M. Rosse, "The archipelago Economy: Unleashing Indonesia's potential," 2012.

[5] M. Voke, I. Fairley, M. Willis, and I. Masters, "Economic evaluation of the recreational value of the coastal environment in a marine renewables deployment area," Ocean Coast. Manag., 2013.

[6] Profwork.org, "The Public Policy Cycle," East. Model, 2014.

[7] M. Perry, "Public Policy," in International Encyclopedia of Human Geography, 2009.

[8] T. R. Dye, Understanding Public Policy, Fourteenth Edition. United State: Pearson Education, 2013.

[9] R. E. Goodin, M. Moran, and M. Rein, The Oxford Handbook of Public Policy. 2009.

[10] T. R. Dye, Understanding Public Policy. 2016.

[11] W. N. Dunn, Pengantar Analisis Kebijakan Publik edisi kedua. Yogyakarta: Gajah Mada University Press, 2003.

[12] D. L. Weimer and A. R. Vining, Policy analysis: Concepts and practice. 2017.

[13] A. Maksimilianus Gai and I. Soemarno, "Sustainable Livelihood-Based Coastal Area Development Model in Surabaya Coastal City, Indonesia," ISSN, 2014.

[14] C. B. Barrett and M. R. Carter, "The Economics of Poverty Traps and Persistent Poverty: Empirical and Policy Implications," J. Dev. Stud., 2013.

[15] T. K. Bradshaw, "Theories of Poverty and Anti-Poverty Programs in Community Development," 
Community Dev., 2007.

[16] J. McCarthy and M. Sumarto, "Distributional politics and social protection in Indonesia: Dilemma of layering, nesting and social fit in Jokowi's poverty policy,” J. Southeast Asian Econ., 2018.

[17] [RI] Republik Indonesia, "Undang-Undang Republik Indonesia Nomor 45 Tahun 2009 tentang Perubahan Atas Undang-Undang Nomor 31 Tahun 2004 tentang Perikanan,” Bho Kkp Ri, 2009.

[18] N. L. Hasanuddin, N. Noor, and H. R. Santosa, "Is it possible to eradicate poverty in the fishermen village ?,” Int. J. Environ. Sci., 2013.

[19] M. A. Rahman, S. Akter, S. Bhowmik, M. M. H. Pramanik, and A. N. Alam, "Fish in super-shops: A new dimension of fish marketing system in Dhaka (Bangladesh)," J. Fish., 2017.

[20] R. M. Yusuff, M. R. Hussain, N. Latif, A. A. Rahman, S. N. S. A. Rashid, and H. Abdullah, "Occupational safety issues at workplace among older fishermen in Malaysia," in New Ergonomics Perspective - Selected Papers of the 10th Pan-Pacific Conference on Ergonomics, 2015.

[21] S. Angelopoulos, F. Kitsios, and T. Papadopoulos, "New service development in e-government: Identifying critical success factors," Transform. Gov. People, Process Policy, 2010.

[22] FAO, The State of World Fisheries and Aquaculture 2018 - Meeting the sustainable development goals. 2018. 